\title{
The Olympic spirit to create campus sports culture by way of what it ought to be
}

\author{
Qiong Huang \\ Jiangxi Institute Of Fashion Technology, NanChang, Jinagxi, China \\ Xuexi123@163.com
}

Key words: Olympic spirit; campus; sports culture; youth.

\begin{abstract}
Olympic spirit encourages people to actively participate in sports, and will enrich the advanced sports facilities into the public view, will be fair competition, solidarity, cooperation, self-improvement, Endeavour more than other useful ideas passed to the majority of people, it has a unique connotation and charm of sports spirit, but the campus sports culture is not optimistic. With the influence of the Olympic spirit on the campus sports culture, it is to find out the physical, institutional and spiritual aspects of school sports culture, and to some extent, it also affects the collective sense of honor and patriotism, which helps to establish the socialist rule of law, promote the development of social spiritual civilization and improve the quality of the people.
\end{abstract}

\section{Introduction}

The connotation of the Olympic spirit. Pierre de Coubertin, father of the modern Olympic Games, first proposed the "higher, faster, stronger", later borrowed by the Olympic movement to and expressed the Olympic movement is not satisfied with the status quo, continue to forge ahead, the courage to innovate and explore, continue to find new direction, scaled new heights, it has a indomitable spirit and to include it in the goal of the Olympic movement [1]. The essence of the spirit of the Olympic spirit is "participation is more important than winning," Coubertin explained: "life is not a victory but a struggle. Its essence is not to win, but to make people more cautious, more health, more beautiful. The Olympic spirit is human a diligent to the spirit of beauty, really, to do good deeds, reflecting the human forever upward, strives constantly for self-improvement the spirit .

Connotation of campus sports culture. The campus sports culture is the main content of the students, taking the extracurricular sports activities as the main content, taking the campus as the main space, the campus spirit as a group culture, campus culture as a kind of social culture, but also in certain social politics, economy, culture, education, sports and other conditions, by the majority of teachers and students in the practice of sports material wealth and spiritual wealth [2]. The campus sports culture is a kind of cultural phenomenon which our country studies sports. It can be said that it is a kind of non material sports which is produced by the school sports culture. Because of the particularity of the environment and the special nature of the people, the campus sports culture is unique.

In the school of physical education, sports teaching, school sports, school sports teams, community activities, etc., these are the sports of the school, and at the same time, these sports are also produced by the sports culture phenomenon, the school organization of all kinds of sports competitions and activities, school sports competitions and activities, school sports competitions and activities, school sports competitions and activities, the school sports competitions and activities. Publicity more sensational, the enthusiasm of the students to participate in an 
unprecedented high,these phenomena are the development of the campus culture construction of Beijing Olympic games[3].

\section{The role of the Olympic spirit on the campus sports culture}

Olympic spirit is a basic spirit which is advocated by the Olympic movement. Progressive, fair competition spirit broken, here no racial discrimination, no war troubles, but only peaceful, friendly and harmonious philosophy, it can be said to be a successful inspirational works, and the Olympic spirit itself is beyond the scope of pure sports, the richness of the connotation, widely and incentive is a way of education, the spirit of the campus sports culture to enhance a certain height, and lay a solid foundation for the campus sports culture. The stimulating effect of the Olympic Games on campus sports culture is mainly reflected in three aspects: the physical culture of campus sports, the sports system culture and the behavior of the campus, and the deeper level of sports spirit culture[4].

Olympic spirit on the construction of campus sports material culture. The basis and material guarantee of the construction of campus sports culture is the physical culture of campus sports, including sports equipment, sports buildings, sports venues and facilities, sports and other sports related physical entities[5]. However, sports material culture is not only refers to the material itself, but also includes the idea and the idea of sports material, such as sports statues, architecture and site facilities will be injected into the wisdom of the designer, embodies the sport's sentiment, will and ideas[6]. In the campus sports in our country, every school represents is a collective, collective ownership have sports competition mechanism, so each school for their campus sports culture and construction of attached great importance, and good sports venues and perfect sports facilities is a foundation for the development of campus sports, but also improve the campus sports competition ability is an important guarantee, become a sports competition between schools. School of a few culture sculpture, campus path name contains all the rich cultural background. Therefore, the school can consider in the gym, some sports venues erected sports sculpture, architectural modeling and, let the students feel the connotation of sports, sports experience, speed, fortitude, and gentle, let Olympic brings positive energy can be widely spread in the campus[7].

Olympic spirit on the construction of campus sports system culture. The core content of the Olympic movement is to actively participate in sports, and in the process of sports, to achieve excellent results, each other with love, and in which continue to transcend themselves, hone their own, dedication[8]. These qualities are also an important guiding ideology of the construction of campus sports system in our country. The campus sports system is urging the young people to actively participate in physical exercise. Schools should have a sound sports regulations, can improve and effectively manage students' sports activities, enrich sports content, campus sports system culture is the link between material and spiritual and cultural level, it is the embodiment of sports consciousness, but also the campus sports organization form, it covers sports teaching, sports rules and regulations, extracurricular sports activities, fitness training, sports organizations, sports exchanges and sports knowledge, such as the full range of knowledge and so on.

Olympic spirit on the construction of campus sports spiritual culture. Sports spirit culture is the most stable and lasting content in the construction of campus sports culture, and it plays a leading role in the material and spiritual aspects. The Olympic spirit after a hundred years of history is timeless, the Olympic spirit promote participation, this gives young people a correct concept of sports, don't care too much about winning or losing, more important is to participate in sports, campus, and more schools organize students to participate in physical exercise, cultivate students' correct view of competition; in addition also, the Olympic spirit emphasizes the spirit of solidarity, 
and this is the important thought of school education is consistent, surviving in the society life, the collective life is greater than the individual sports, and even more so, whether it is a collective project or personal project, the success of a person, always have many people, for the dedication the sacrifice in return.

\section{Analysis of the status quo of campus sports culture}

In the history, culture and social background, the authority of the campus sports culture has deprived the subjective use and activity of the main body of education. In addition, because of the type of school, the law and the teachers' condition, there are obvious differences in the level of the geography and environment, the level of the campus and the construction funds. On the whole, the current situation of campus sports culture in China is not optimistic[9].

Sports equipment facilities, lack of space. Through the author's visit and observation, found that many schools and secondary vocational schools due to the lack of school buildings and not with the standard 400 meters of plastic runway, more outrageous things are still the focus of the province, the city is still used for the soil playground, in addition to some school sports equipment facilities, equipment is old, far can't meet the normal sports teaching needs, once encountered rainy, playground is like a fish pond. If you can 't meet the basic needs of the students' physical education, how to enhance students' physique? Therefore, how to overcome the lack of equipment, to meet the normal teaching needs, should be recommended to the municipal, Provincial Department of education leadership in accordance with the requirements of the State Board of education, to strengthen the leadership of the leadership of sports awareness, open up quality sports venues, increase or update the school sports equipment facilities, to ensure that students love sports, outdoor sports, so that school sports can be carried out smoothly and form a good sports culture atmosphere.

Leadership of physical education teaching quality and concept. The school leader in the pursuit of academic performance, skills development, employment rate, etc., but neglect the establishment, dissemination and implementation of the campus sports culture, which leads to a lot of students' interest in sports, sports behavior is reduced, so that students' physical fitness decreased significantly. In addition, teaching evaluation is often targeted at the leadership of the high employment rate of professional, leadership often focus on the core strength of the city, the province's key professional hardware, software investment and construction. Sports in school sports education training is often not the some value, physical education teachers have become dispensable. Teaching quality is becoming lower and lower, the way of evaluation and assessment is too sloppy, venues and facilities have greatly restricted, inadequate staffing, mass sports activity effect is poorer, student participation desire does not lead to higher school sports teaching quality and effect is generally low[10].

Physical education teachers work under pressure, many things. Whether inside or outside of the teachers there are prejudice and discrimination of PE teachers, sports teachers is also a teacher of the people, with their skills, knowledge, personality charm, as a way of communicating imparting knowledge and skills and life experience to students, in the face of many miscellaneous things class, facing the outdoor open teaching environment, under the scorching sun, to pull the throat to shout password, students' safety accidents happened and fear, every day classes sweating, dry mouth, than indoor culture class teachers to write, pronouncing courseware workload much larger, so they should have with other teachers equal treatment and non discrimination. However, this is not the case. World of sports teachers dismissive, is even inside the school teachers so treat them and set team, team, free activities, trooped, dissolution which is the basic process, teachers do not have the basic class, working surface difficile rhetoric. Outside of the physical education teachers in addition 
to sessional teaching tasks are also responsible for school assembly arrangement of large and small, different levels of physical training of team work, the student physique health test a series of teaching activities even more. However, from various schools generally lack of situation will lead to school physical education teachers work is more busy.

School lack of campus sports cultural signs. Sports is the weak link in promoting the quality education, students' physical health status is worrying. The symbol of culture is not only a kind of language phenomenon, but also a cultural phenomenon, can give a person a kind of psychological suggestion and power. Sports cultural signs are usually positive, upward and dynamic, which have a positive effect on the development of people. By the author of each school visits and observed that many small and medium-sized schools lack of campus sports culture banners and billboards, students is difficult in the heart to establish a healthy, upward positive concept and consciousness. Therefore, the school is difficult to form unique, rich campus culture, sports concept of school characteristics, group identity, which on active fitness, set good sports view to have the very big negative effect.

\section{Olympic spirit on the campus sports culture should be the track}

Strengthen the construction of physical culture in the secondary school. Sports architecture, sculpture, and facilities, venues and so on, they are themselves a cultural phenomenon, is the essence of human power. At the same time, they have become the carrier of the consciousness culture, embodies the human knowledge, ideas and wisdom, embodies the people's sentiment, will, value, and other cultural characteristics, these characteristics will reflect people's mind, the people play a subtle role in the cultivation of. In addition, sports buildings, facilities, venues, etc., as a kind of support, but also to bear the physical exercise of teachers and students. Therefore, efforts should be made to create conditions to strengthen the construction of sports material culture, including the construction of stadiums, the purchase of facilities and the use of good and reasonable facilities and supplies.

Promote students to form a good ideological and moral character. The campus sports culture has the function of education and guidance, therefore, it can improve students' Ideological and moral education through the organization's rich and colorful sports activities[11]. Such as the use of a variety of campus media publicity our athletes at home and abroad sports to overcome difficulties and challenges in life, to win glory for the country's deeds, successively to stimulate students' patriotic enthusiasm and national pride, and guide them to form a correct world outlook and values. In addition, to play the characteristics of the sports activities, through the group competition can educate the students love the collective, care for the collective, to maintain the collective, to effectively develop the students' spirit of collectivism.

Strengthen the construction of the campus sports system culture. System and culture form is the rules and regulations that require students to abide by in the teaching of physical education, recreation and competition. The formation system and the process of the system, in fact, is a process of cultural precipitation, the students in school for a variety of sports and training, always be subject to the influence of the system culture, constraints and influence, and to regulate their own behavior. Institutional culture of students plays a certain constraints and guiding role, it can guide students in sports and the competition under the rules of engagement, is conducive to the cultivation of the habit of students strengthen moral cultivation.

Strengthening school spirit, good study style construction. Sports spirit is the core of campus sports culture. In the construction of vocational campus sports culture should be actively advocated the "health first" as the spirit of sports, the sports spirit and school spirit and style of study 
construction of organic combined together, make it become the organic component of school spirit and style of study; the same school leadership attention and sports equipment and facilities complete and PE teachers happy work to promote school spirit and style of study construction play an important role. In this way, the students are engaged in the rich

The campus sports culture, disseminated full of vigor and vitality of the spirit of the atmosphere in, they formed aggressive mood, strenuous efforts feelings and state of mind will be optimized, their sentiments are cultivated, school spirit and style of study in order to truly become guide the behavior of students.

Enhancing the openness of campus sports culture. The sports culture of the campus should keep the contact with the society and culture, and strengthen the communication with the society and culture. Slower update of the traditional physical education content, form a single, lost the openness of the sports culture, open of the sports culture in various forms, rich in content and can bring a lot of new information and social information to the students, let the students learning in physical education and increase the understanding of society, school leaders and the teacher in charge should lead from the teachers and other school interscholastic friendship and competition, raises the student physical training habits and awareness[12]. The effect of this radiation can be achieved by the integration of school culture and social culture, and to maintain the openness of sports culture.

\section{References}

[1] John H. C. Colson. Frank W. Collison. PROGRESSIVE EXERCISE THERAPY

IN REHABILITATION AND PHYSICAL EDUCATION [M]. Fully Revised. Fourth Edition. P137.

[2] Nancy Giebel , Ed .D. Great Job For Physical Education Majors [M]. The McGraw-Hill Companies,Inc.P37.

[3] Michael Monahan. The Practice of Self-Overcoming: Nietzschean Reflections on the Martial Arts. [J] Journal of the Philosophy of Sport, 2012, 34.p39-51

[4] Ann E. Cudd. Sporting Metaphors: Competition and the Ethos of Capitalism[J]. Journal of the Philosophy of Sport, 2013, 34, P52-67.

[5] A. Walsh and R. Giulianotti. Ethics, Money, and Sport: This Sporting Mammon. Journal of the Philosophy of Sport, 2006, 35, P 225-228.

[6] Craig L. Carr. Fairness and Performance Enhancement in Sport[J]. Journal of the Philosophy of Sport, 2010, 35, P193-207

[7] Scott Kretchmar. Gaming Up Life: Considerations for Game Expansions[J].

Journal of the Philosophy of Sport, 2008, 35, P142-155.

[8] Seth Vannatta. A Phenomenology of Sport: Playing and Passive Synthesis[J]. Journal of the Philosophy of Sport, 2009, 35, P63-72

[9] Randolph Feezell. Vulgarians of the World Unite: Sport, Dirty Language, and Ethics[J]. Journal of the Philosophy of Sport, 2008, 35, P17-42

[10] Cesar R. Torres and Peter F. Hager. De-emphasizing Competition in Organized

Youth Sport: Misdirected Reforms and Misled Children[J]. Journal of the Philosophy of Sport, 2007, 34, P194-210 
[11] Hans Ulrich Gumbrecht. Published 2006 by Belknap Press at Harvard Press, Cambridge, MA. In Praise of Athletic Beauty[J]. Journal of the Philosophy of Sport, 2007, 34, P100-101.

[12] Ann E. Cudd. Sporting Metaphors: Competition and the Ethos of Capitalism[J] . Journal of the Philosophy of Sport, 2007, 34, P52-67. 